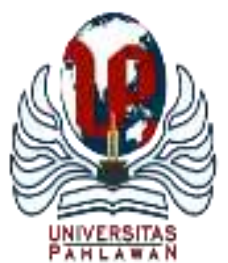

Edukatif : Jurnal Ilmu Pendidikan Volume 3 Nomor 6 Tahun 2021 Halm 4659 - 4670

EDUKATIF: JURNAL ILMU PENDIDIKAN

Research \& Learning in Education

https://edukatif.org/index.php/edukatif/index

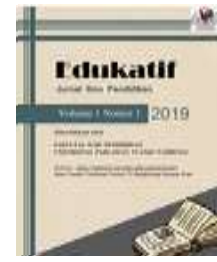

\title{
Inovasi di Era Informasi: Analisis Kepemimpinan Transformasional dan Iklim Etis di Industri Manufaktur
}

\author{
Beby Tiara $^{1 凶}$, Vanessa Stefanny ${ }^{2}$, Sukriyah $^{3}$, Dewiana Novitasari $^{4}$, Masduki Asbari $^{5}$ \\ STMIK Insan Pembangunan, Indonesia ${ }^{1,2,5}$ \\ Sekolah Tinggi Ilmu Ekonomi Insan Pembangunan, Indonesia ${ }^{3,4}$ \\ E-mail : bebytiara27@gmail.com ${ }^{1}$, fannybataona@gmail.com ${ }^{2}, \underline{\text { simplechissy@gmail.com }}^{3}$, \\ dhewiediosa@yahoo.co.id ${ }^{4}$, kangmasduki.ssi@gmail.com ${ }^{5}$
}

\begin{abstract}
Abstrak
Era informasi yang membuka ruang kompetisi secara bebas dan meluas telah menantang setiap organisasi bisnis, termasuk industry manufaktur untuk mengasah keunggulan kompetitifnya. Ikon utama keunggulan kompetitif itu adalah perilaku inovatif dari setiap pegawainya. Oleh karena itu, tujuan penelitian ini adalah menguji pengaruh kepemimpinan transformasional dan iklim etis terhadap perilaku inivatif pegawai dengan mengambil 126 pegawai pada industri manufaktur di Kabupaten Tangerang Banten dengan teknik Simple Random Sampling. Analisis dari penelitian ini menggunakan SEM (Structural Equation Model) dengan software SmartPLS versi 3.0 sebagai alat bantu statistik. Hasil dari penelitian ini menunjukkan bahwa kepemimpinan transformasional memberikan efek positif dan signifikan terhadap iklim etis, kepemimpinan transformasional memberikan efek positif dan signifikan terhadap perilaku inovatif pegawai, baik secara langsung maupun tidak langsung melalui mediasi iklim etis.
\end{abstract}

Kata kunci: Iklim etis, kepemimpinan transformasional, perilaku inovatif.

\section{Abstract}

The information age that opens up the competition space freely and widely has challenged every business organization, including the manufacturing industry, to hone its competitive advantage. The main icon of competitive advantage is the innovative behavior of every employee. Therefore, the purpose of this study was to examine the effect of transformational leadership and ethical climate on employee innovative behavior by taking 126 employees in the manufacturing industry in Tangerang Banten Regency using the Simple Random Sampling technique. The analysis of this study uses SEM (Structural Equation Model) with SmartPLS software version 3.0 as a statistical tool. The results of this study indicate that transformational leadership has a positive and significant effect on the ethical climate, transformational leadership has a positive and significant effect on the innovative behavior of employees, either directly or indirectly through the mediation of the ethical climate.

Keywords: Ethical climate, innovative behavior, transformational leadership.

Copyright (c) 2021 Beby Tiara, Vanessa Stefanny, Sukriyah, Dewiana Novitasari, Masduki Asbari

$\triangle$ Corresponding author

Email : bebytiara27@gmail.com

DOI $\quad$ : https://doi.org/10.31004/edukatif.v3i6.1540 
4660 Inovasi di Era Informasi: Analisis Kepemimpinan Transformasional dan Iklim Etis di Industri Manufaktur Beby Tiara, Vanessa Stefanny, Sukriyah, Dewiana Novitasari, Masduki Asbari

DOI: https://doi.org/10.31004/edukatif.v3i6.1540

\section{PENDAHULUAN}

Setiap perusahaan manufaktur membutuhkan track yang sesuai dengan core bisnisnya, sehingga terukur dalam setiap laju tumbuh kembangnya. Di sinilah urgensi budaya atau iklim etis didefinisikan, dibangun dan dirawat. Di tengah budaya masyarakat Indonesia yang memiliki patronasi kuat, maka tidak bisa dipungkiri bahwa pengaruh patron, anutan, pengatur atau pimpinan akan menjadi faktor prediktor kesuksesan organisasi yang sangat menonjol. Banyak teori kepemimpinan yang dikemukakan guna mengkatalisasi proses dan mengkanalisasi sumber daya manusia. Setidaknya, teori kepemimpinan transformasional merupakan satu dari banyak teori kepemimpinan yang dipercaya mampu membawa angin segar perubahan organisasi. Lebih-lebih di era Revolusi Industri 4.0 ini, setiap organisasi membutuhkan pemimpin yang mempunyai kapabilitas cukup guna melakukan transformasi menuju digitalisasi struktur dan sistem organisasi. (Asbari et al., 2021b, 2021a; Fikri et al., 2021; Novitasari et al., 2021; Pramono et al., 2021) melakukan penelitian dan mendapatkan hasil bahwa kepemimpinan transformasional berpengaruh signifikan dan positif terhadap kinerja pegawai. Budaya organisasi, dalam hal ini iklim etis merupakan salah satu factor penting untuk membangun sumber daya manusia melalui aspek perubahan sikap dan perilaku, yang diharapkan mampu menyesuaikan diri dengan tantangan yang sedang berjalan dan yang akan datang (Ebtsam, 2015; Nedkovski et al., 2017). Iklim etis merupakan suatu kekuatan sosial yang tidak tampak, yang dapat menggerakkan orang-orang dalam suatu organisasi untuk melakukan aktivitas kerja. Iklim etis yang kuat mendukung tujuan-tujuan perusahaan ataupun instansi pemerintahan. Iklim etis memiliki peranan penting dalam mengelola suatu organisasi karena merupakan persepsi yang sama dan utuh tentang makna hakiki kehidupan bersama dalam organisasi.

Kepala Badan Kebijakan Fiskal (BKF), Kementerian Keuangan, Febrio Kacaribu menyatakan bahwa senjata utama bangkitnya dunia usaha saat ini tidak bisa hanya bergantung pada kebijakan fiskal dari pemerintah, tetapi juga pada kemampuan industri dalam berinovasi menciptakan produk yang mampu memenuhi kebutuhan masyarakat (Sukarno, 2020). Pada era digital inilah makin terasa dibutuhkan level inovasi dan kreativitas yang lebih tinggi dari setiap anggota organisasi. Teori inovasi sering kali menekankan bahwa inovasi lebih luas dari kreativitas dan di dalamnya termasuk implementasi dari ide-ide yang dikreasikan. Oleh karena itu, De Jong dan Den Hartog mengembangkan innovative work behavior (IWB), tidak hanya untuk memaparkan masalah bagaimana menghasilkan ide tetapi juga membangun perilaku yang dibutuhkan untuk implementasi ide-ide tersebut. Ujung dari proses pengembangan IWB ini adalah meningkatkan kinerja individu maupun organisasi (Jong \& Hartog, 2008).

Kata iklim mengandung arti kecenderungan dan inklinasi. Istilah dari literatur manajemen, iklim berarti persepsi anggota organisasi terhadap kondisi organisasi saat ini. Iklim etis pada dasarnya adalah digambarkan sebagai praktik dan prosedur perusahaan yang menjelaskan tentang perilaku karyawan (Ebtsam, 2015). Victor dan Cullen mendefinisikan iklim etis sebagai persepsi umum tentang bagaimana mengatasi masalah etika dan apa perilaku yang layak dari segi etika (Nedkovski et al., 2017). Tidak hanya kepentingan individu, kelompok, dan perusahaan tetapi juga tanggung jawab sosial korporasi, prosedur dan standar perusahaan serta faktor lingkungan, seperti peraturan perundang-undangan memiliki peran dalam pembentukan iklim etis (Ebtsam, 2015). Di antara faktor-faktor yang mempengaruhi perilaku inovatif karyawan adalah hubungan pemimpinanggota, karakteristik pekerjaan dan iklim organisasi (Topcu et al., 2015). Fakta bahwa perilaku kerja inovatif menunjukkan struktur dinamis yang menunjukkan bahwa pegawai lebih mudah terpengaruh oleh iklim organisasi (Topcu et al., 2015). Selain itu, jenis kepemimpinan memainkan peran penting dalam persepsi, pembentukan dan keberlanjutan persepsi etis seorang karyawan. Peran kepemimpinan dalam penciptaan iklim etis ini telah telah dibuktikan dengan temuan (Topcu et al., 2015).

Berdasarkan kajian berbagai referensi yang dilakukan hingga September 2021, belum banyak peneliti nasional yang membahas pengaruh kepemimpinan transformasional dan iklim etis terhadap perilaku 
4661 Inovasi di Era Informasi: Analisis Kepemimpinan Transformasional dan Iklim Etis di Industri Manufaktur Beby Tiara, Vanessa Stefanny, Sukriyah, Dewiana Novitasari, Masduki Asbari

DOI: https://doi.org/10.31004/edukatif.v3i6.1540

kerja inovatif sebagai satu kesatuan model penelitian. Di Indonesia, beberapa penelitian telah membahas pengaruh kepemimpinan transformational terhadap perilaku kerja inovatif (Asbari, Fayzhall, et al., 2020; Asbari, Purwanto, et al., 2020). Temuan mereka adalah bahwa variabel kepemimpinan transformasional berpengaruh terhadap perilaku inovatif. Berbeda dengan hasil penelitian yang dilakukan oleh Wardhani \& Gulo (2017) dengan hasil yang bertolak belakang, yakni bahwa kepemimpinan transformasional tidak memiliki pengaruh terhadap perilaku kerja inovatif. Di luar itu, beberapa peneliti nasional telah membahas dan menyimpulkan bahwa terdapat kepemimpinan transformasional berpengaruh signifikan terhadap perilaku kerja inovatif (Khasanah \& Himam, 2019; Octavia \& Ratnaningsih, 2017; Setyowati \& Etikariena, 2019). Sedangkan Asbari, (2019a) melakukan penelitian dan menyimpulkan bahwa kepemimpinan transformasional dan budaya organisasi berpengaruh signifikan dan positif terhadap perilaku inovatif. Hanya saja kesemuanya belum ada yang menjelaskan relasi kedua variable (kepemimpinan transformasional dan perilaku inovatif) dengan iklim etis.

Oleh karena itu, peneliti memandang perlu memastikan praktik kepemimpinan transformasional dalam pengaruhnya terhadap iklim etis dan perilaku inovatif pegawai di industry manufaktur. Penelitian ini adalah yang pertama, atau setidaknya sangat jarang dilakukan pada unit analisis industry manufaktur. Di samping itu, telah banyak penelitian yang membahas pengaruh langsung kepemimpinan transformasional terhadap perilaku inovatif pegawai, tapi penelitian ini membahas hubungan langsung sekaligus hubungan pengaruh tidak langsung kepemimpinan transformasional terhadap perilaku inovatif pegawai di industry manufaktur melalui iklim etis, yang mana masih sangat jarang diteliti.

\section{METODE PENELITIAN}

Menurut Creswell \& Creswell (2017), jika tujuan dari penelitian ini adalah untuk mengetahui hubungan pengaruh antar variabel yang diteliti, maka pendekatan kuantitatif adalah yang terbaik. Metode penelitian kuantitatif adalah cocok dalam menguji teori dan hipotesis melalui penggunaan seperangkat alat statistik (Creswell \& Creswell, 2017). Oleh karena itu, penelitian ini menggunakan metode survei untuk menguji hipotesis yang dirumuskan. Oleh karena itu, diadopsi kuesioner digunakan sebagai instrumen untuk mengumpulkan data yang dibutuhkan. Populasi penelitian terdiri dari 205 pegawai sebuah industri manufaktur di Tangerang. Dengan menggunakan simple random sampling, 205 kuesioner dikirim secara online kepada populasi. 126 kuesioner dikembalikan dan valid, yang membentuk tingkat tanggapan $61,5 \%$. Oleh karena itu, manurut Roscoe et al. (1975) jumlah sampel yang diperoleh sudah memadai.

Sifat penelitian ini melibatkan efek dependen antara konstruk laten dan variabel manifest, oleh karena itu, model pengukuran reflektif cocok untuk penelitian ini (Hair Jr et al., 2017). Semua item yang diadopsi dinilai pada skala Likert lima poin dari 1 (sangat tidak setuju) sampai 5 (sangat setuju). Instrumen kepemimpinan transformasional, lima item (KT1-KT5) diadaptasi dari Bogler (2001). Instrumen untuk mengukur iklim etis, enam item (IE1-IE6) mengadopsi dari Schwepker (2001) yang telah divalidasi oleh Briggs et al. (2012). Sedangkan untuk mengukur perilaku kerja inovatif, lima item (PI1PI5) mengadaptasi dari Jong \& Hartog (2008).

Teknik statistik paling populer di bawah Structural Equation Model SEM adalah berbasis kovarian pendekatan (CB-SEM) dan teknik kuadrat terkecil parsial berbasis varian (PLS-SEM) (Sarstedt et al., 2014). Namun, PLS-SEM akhir-akhir ini mendapat perhatian yang luas di banyak orang disiplin ilmu seperti pemasaran, manajemen strategis, sistem informasi manajemen, dan cabang keilmuan lainnya (Hair et al., 2012). Kemampuan PLS-SEM untuk menangani permasalahan problematic modelling yang biasa terjadi di lingkungan social ilmu pengetahuan seperti karakteristik data yang tidak biasa (misalnya data non-normal) dan model yang sangat kompleks adalah alasan penting di balik peningkatan penggunaan pendekatan ini. Mengingat keuntungan dari pendekatan ini, penelitian ini menggunakan PLS-SEM untuk menguji secara 
4662 Inovasi di Era Informasi: Analisis Kepemimpinan Transformasional dan Iklim Etis di Industri Manufaktur Beby Tiara, Vanessa Stefanny, Sukriyah, Dewiana Novitasari, Masduki Asbari

DOI: https://doi.org/10.31004/edukatif.v3i6.1540

keseluruhan dari hipotesis yang diajukan. Perangkat lunak SmartPLS 3.0 dilakukan untuk mengevaluasi masing-masing outer model dan inner model. Pengujian outer model dilakukan untuk memastikan keandalan dan validitas pengukuran, sedangkan hipotesis yang diperkenalkan diperiksa melalui inner model. Selanjutnya, hasil akhir kuesioner yang kemudian digunakan pada penelitian ini sebagaimana disebutkan pada Tabel 1.

Tabel 1. Daftar Item Penelitian

\begin{tabular}{ll}
\hline Notasi & Item \\
\hline Kepemimpinan Transformasional (KT) \\
\hline KT1 & Pimpinan memproyeksikan dirinya sebagai panutan dan teladan \\
\hline KT2 & $\begin{array}{l}\text { Pimpinan menunjukkan bakat dan kemampuannya dalam mengatasi masalah } \\
\text { dengan pengambilan keputusan yang tepat }\end{array}$ \\
\hline KT3 & Pimpinan berusaha mencapai tujuan kolektif untuk memenuhi misi \\
\hline KT4 & Pimpinan menyajikan tantangan dan proyek baru \\
\hline KT5 & $\begin{array}{l}\text { Pimpinan percaya pada kemampuan pegawainya untuk menghadapi tantangan dan } \\
\text { hambatan }\end{array}$ \\
\hline
\end{tabular}

\begin{tabular}{ll}
\hline Iklim Etis (IE) \\
\hline IE1 & [Perusahaan] secara ketat menegakkan kode etik. \\
\hline IE2 & [Perusahaan] memiliki kebijakan mengenai perilaku etis. \\
\hline IE3 & [Perusahaan] secara ketat menegakkan kebijakan mengenai perilaku etis. \\
\hline IE4 & $\begin{array}{l}\text { Manajemen puncak di [Perusahaan] telah memberitahukan dengan tegas bahwa } \\
\text { perilaku tidak etis tidak akan ditoleransi. }\end{array}$ \\
\hline IE5 & $\begin{array}{l}\text { Jika seorang pegawai di [Perusahaan] diketahui terlibat dalam perilaku tidak etis yang } \\
\text { terutama menghasilkan keuntungan pribadi (bukan keuntungan perusahaan), dia akan } \\
\text { segera ditegur. }\end{array}$ \\
\hline IE6 & $\begin{array}{l}\text { Jika seorang pegawai di [Perusahaan] diketahui terlibat dalam perilaku tidak etis yang } \\
\text { terutama menghasilkan keuntungan perusahaan (bukan keuntungan pribadi), dia akan } \\
\text { segera ditegur. }\end{array}$ \\
\hline Perilaku Inovatif (PI) \\
\hline PI1 & Saya mencoba menghasilkan ide-ide kreatif untuk meningkatkan kinerja \\
\hline PI2 & Saya mencoba mencari teknologi, proses, teknik, dan/atau ide baru \\
\hline PI3 & $\begin{array}{l}\text { Saya mengembangkan rencana dan jadwal yang memadai untuk implementasi ide-ide } \\
\text { baru }\end{array}$ \\
\hline PI4 & Saya mempromosikan dan memperjuang-kan ide kepada orang lain \\
\hline PI5 & Saya adalah seorang yang inovatif \\
\hline
\end{tabular}

Menurut Sekaran \& Bougie (2003) kerangka teoritis merupakan fondasi di mana seluruh proyek penelitian didasarkan. Dari kerangka teoritis bisa disusun hipotesis yang dapat diuji untuk mengetahui apakah teori yang dirumuskan valid atau tidak. Lalu kemudian selanjutnya akan dapat diukur dengan analisis statistik yang tepat. Untuk itu, penulis membangun model penelitian sebagai mana disebut pada Gambar 1 berikut: 
4663 Inovasi di Era Informasi: Analisis Kepemimpinan Transformasional dan Iklim Etis di Industri Manufaktur Beby Tiara, Vanessa Stefanny, Sukriyah, Dewiana Novitasari, Masduki Asbari

DOI: https://doi.org/10.31004/edukatif.v3i6.1540

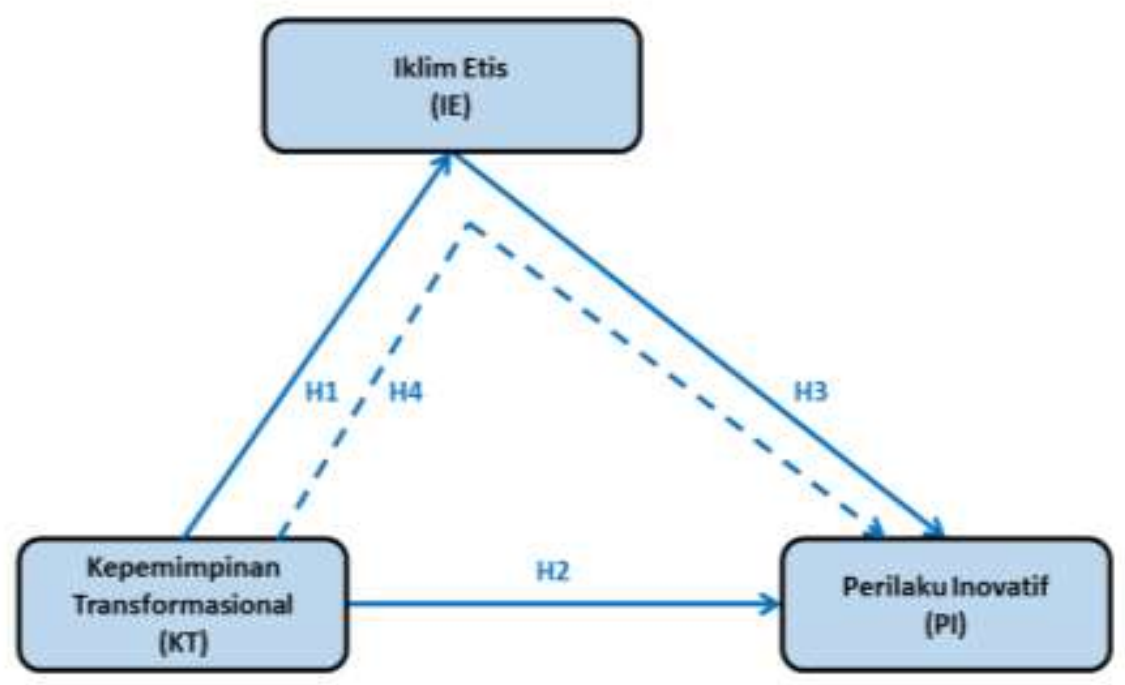

Gambar 1. Model Penelitian

Maka berdasarkan kajian pustaka sebelumnya, maka disusun hipotesis sebagai berikut:

H1: Kepemimpinan transformasional berpengaruh positif dan signifikan terhadap iklim etis

$\mathrm{H} 2$ : Kepemimpinan transformasional berpengaruh positif dan signifikan terhadap perilaku inovatif pegawai

H3: Iklim etis berpengaruh positif dan signifikan terhadap perilaku inovatif pegawai

H4: Kepemimpinan transformasional berpengaruh positif dan signifikan terhadap perilaku inovatif pegawai melalui mediasi iklim etis

\section{HASIL DAN PEMBAHASAN}

\section{Hasil}

Total ada 126 pegawai yang berpartisipasi, terdiri dari laki-laki $(78,6 \%)$ dan perempuan $(21,4 \%)$. Responden memiliki kelompok umur yang berbeda-beda, berkisar antara di bawah usia 29 tahun (47,6\%), 3049 tahun $(44,5 \%)$, dan lebih dari usia 50 tahun $(7,9 \%)$. Lama kerja mereka juga beragam, $34 \%$ di antaranya di bawah 5 tahun, 50\% sudah bekerja antara 5-10 tahun, dan 16\% sisanya telah bekerja lebih dari 10 tahun. Pendidikan tertinggi responden adalah mayoritas setingkat SLTA (SMA/SMK) yakni 75\%, dan sisanya 25\% adalah lulusan sarjana.

Tahap pengujian model pengukuran meliputi pengujian validitas konvergen, validitas diskriminan. Sementara untuk menguji reliabilitas konstruk digunakan nilai cronbach's alpha dan composite reliability. Hasil analisis PLS dapat digunakan untuk menguji hipotesis penelitian jika seluruh indikator dalam model PLS telah memenuhi syarat validitas konvergen, validitas deskriminan dan uji reliabilitas. Uji validitas konvergen dilakukan dengan melihat nilai loading factor masing-masing indikator terhadap konstruknya. Pada sebagian besar referensi, bobot faktor sebesar 0,7 atau lebih dianggap memiliki validasi yang cukup kuat untuk menjelaskan konstruk laten (Chin, 1998; Ghozali, 2014; J. F. Hair et al., 2010). Pada penelitian ini batas minimal besarnya loading factor yang diterima adalah 0,7 , dan dengan syarat nilai AVE setiap konstruk $>0,5$ (Ghozali, 2014). Setelah melalui pengolahan SmartPLS 3.0, seluruh indikator telah memiliki nilai loading factor di atas 0,7 dan nilai AVE di atas 0,5. Model fit atau valid dari penelitian ini dapat dilihat pada Gambar 2. Jadi dengan demikian, validitas konvergen dari model penelitian ini sudah memenuhi syarat (Purwanto et 
4664 Inovasi di Era Informasi: Analisis Kepemimpinan Transformasional dan Iklim Etis di Industri Manufaktur Beby Tiara, Vanessa Stefanny, Sukriyah, Dewiana Novitasari, Masduki Asbari

DOI: https://doi.org/10.31004/edukatif.v3i6.1540

al., 2019, 2020; Purwanto, Asbari, \& Santoso, 2021b, 2021a; Purwanto, Asbari, Santoso, et al., 2021). Nilai loadings, cronbach's alpha, composite reliability dan AVE setiap konstruk selengkapnya dapat dilihat Tabel 2.

Discriminant validity dilakukan untuk memastikan bahwa setiap konsep dari masing-masing variabel laten berbeda dengan variabel laten lainnya. Model mempunyai discriminant validity yang baik jika nilai kuadrat AVE masing-masing konstruk eksogen (nilai pada diagonal) melebihi korelasi antara konstruk tersebut dengan konstruk lainnya (nilai di bawah diagonal) (Ghozali, 2014). Hasil pengujian discriminant validity adalah dengan menggunakan nilai kuadrat AVE, yakni dengan melihat Fornell-Larcker Criterion Value diperoleh sebagaimana ditunjukkan pada Tabel 3. Hasil uji validitas deskriminan pada tabel 3 menunjukkan bahwa seluruh konstruk telah memiliki nilai akar kuadrat AVE di atas nilai korelasi dengan konstruk laten lainnya (melalui kriteria Fornell-Larcker). Demikian juga nilai cross-loading seluruh item dari suatu indikator lebih besar dari item indikator lainnya sebagaimana disebut pada Tabel 3, sehingga dapat disimpulkan bahwa model telah memenuhi validitas deskriminan (Fornell \& Larcker, 1981).

Selanjutnya dilakukan evaluasi collinearity untuk mengetahui ada tidaknya masalah collinearity pada model. Untuk menemukan collinearity tersebut, diperlukan statistik collinearity VIF dari setiap konstruk. Jika VIF lebih dari 5, maka model memiliki collinearity (Hair et al., 2014). Seperti yang ditunjukkan pada Tabel 4, semua skor VIF kurang dari 5, yakni hasil dari model struktural collinearity mengungkapkan nilai VIF di bawah 2. Hal ini menunjukkan bahwa model penelitian ini tidak ada masalah multikolinearitas.

Reliabilitas konstruk dapat dinilai dari nilai cronbach's alpha dan composite reliability dari masingmasing konstruk. Nilai composite reliability dan cronbach's alpha yang disarankan adalah lebih dari 0,7 (Ghozali, 2014). Hasil uji reliabilitas pada tabel 2 menunjukkan bahwa seluruh konstruk telah memiliki nilai composite reliability dan cronbach's alpha lebih besar dari $0,7(>0,7)$. Kesimpulannya, seluruh konstruk telah memenuhi reliabilitas yang dipersyaratkan.

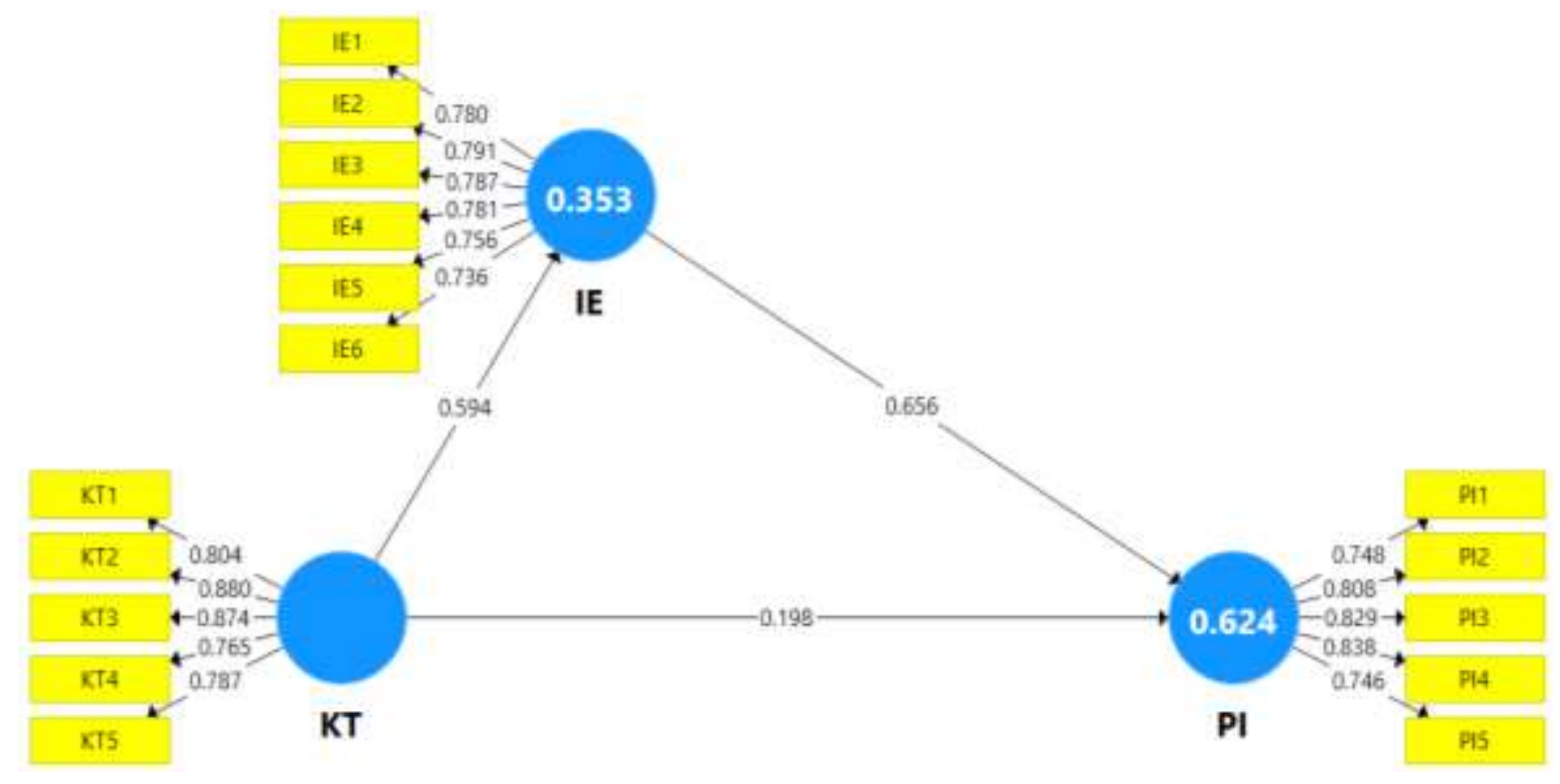

Gambar 2. Model Penelitian Valid

Sumber: Hasil Pengolahan SmartPLS 3.0 (2021) 
4665 Inovasi di Era Informasi: Analisis Kepemimpinan Transformasional dan Iklim Etis di Industri Manufaktur Beby Tiara, Vanessa Stefanny, Sukriyah, Dewiana Novitasari, Masduki Asbari

DOI: https://doi.org/10.31004/edukatif.v3i6.1540

Tabel 2. Items Loadings, Cronbach's Alpha, Composite Reliability, and Average Variance Extracted (AVE)

\begin{tabular}{|c|c|c|c|c|c|c|}
\hline Variables & Items & Loadings & $\begin{array}{l}\text { Cronbach's } \\
\text { Alpha }\end{array}$ & Rho_A & $\begin{array}{l}\text { Composite } \\
\text { Reliability }\end{array}$ & AVE \\
\hline \multirow[t]{5}{*}{$\begin{array}{ll}\text { Kepemimpinan } & \text { Transformasional } \\
(\mathrm{KT})\end{array}$} & KT1 & 0,804 & 0,881 & 0,889 & 0,913 & 0,678 \\
\hline & KT2 & 0,880 & & & & \\
\hline & KT3 & 0,874 & & & & \\
\hline & KT4 & 0,765 & & & & \\
\hline & KT5 & 0,787 & & & & \\
\hline \multirow[t]{6}{*}{ Iklim Etis (IE) } & IE1 & 0,780 & 0,864 & 0,866 & 0,898 & 0,596 \\
\hline & IE2 & 0,791 & & & & \\
\hline & IE3 & 0,787 & & & & \\
\hline & IE4 & 0,781 & & & & \\
\hline & IE5 & 0,756 & & & & \\
\hline & IE6 & 0,736 & & & & \\
\hline \multirow[t]{5}{*}{ Perilaku Inovaatif (PI) } & PI1 & 0,748 & 0,853 & 0,854 & 0,895 & 0,632 \\
\hline & $\mathrm{PI} 2$ & 0,808 & & & & \\
\hline & $\mathrm{PI} 3$ & 0,829 & & & & \\
\hline & PI4 & 0,838 & & & & \\
\hline & PI5 & 0,746 & & & & \\
\hline
\end{tabular}

Tabel 3. Discriminant Validity

\begin{tabular}{llll}
\hline Variables & IE & KT & PI \\
\hline & & & \\
\hline IE & 0,772 & & \\
\hline KT & 0,594 & 0,824 & \\
\hline PI & 0,774 & 0,588 & 0,795 \\
\hline
\end{tabular}

Sumber: Hasil Pengolahan SmartPLS 3.0 (2021)

Tabel 4. Collinearity (VIF)

\begin{tabular}{lccc}
\hline Variables & IE & KT & PI \\
\hline & & & \\
\hline IE & & 1,546 \\
\hline KT & 1,000 & 1,546 \\
\hline PI & & \\
\hline
\end{tabular}

Sumber: Hasil Pengolahan SmartPLS 3.0 (2021)

Tabel 5. Nilai $R$ Square

\begin{tabular}{lcc}
\hline Variables & R Square & $\begin{array}{c}\text { R Square } \\
\text { Adjusted }\end{array}$ \\
\hline IE & 0,353 & 0,353 \\
\hline PI & 0,624 & 0,623 \\
\hline
\end{tabular}

Sumber: Hasil Pengolahan SmartPLS 3.0 (2021) 
4666 Inovasi di Era Informasi: Analisis Kepemimpinan Transformasional dan Iklim Etis di Industri Manufaktur Beby Tiara, Vanessa Stefanny, Sukriyah, Dewiana Novitasari, Masduki Asbari

DOI: https://doi.org/10.31004/edukatif.v3i6.1540

Tabel 6. Hypotheses Testing

\begin{tabular}{llllllll}
\hline Hypotheses & Relationship & $\begin{array}{l}\text { Origina } \\
1 \\
\text { Sample } \\
(\mathrm{O})\end{array}$ & $\begin{array}{l}\text { Sample } \\
\text { Mean } \\
(\mathrm{M})\end{array}$ & $\begin{array}{l}\text { Standard } \\
\text { Deviation } \\
(\mathrm{STDEV})\end{array}$ & $\begin{array}{l}\text { T Statistics } \\
(|\mathrm{O} / \mathrm{STDEV}|)\end{array}$ & P Values & Decision \\
\hline H1 & KT -> IE & 0,594 & 0,594 & 0,026 & 22,911 & 0,000 & Didukung \\
\hline H2 & KT -> PI & 0,198 & 0,198 & 0,027 & 7,234 & 0,000 & Didukung \\
\hline H3 & IE -> PI & 0,656 & 0,657 & 0,025 & 26,493 & 0,000 & Didukung \\
\hline H4 & KT -> IE -> PI & 0,390 & 0,390 & 0,024 & 15,961 & 0,000 & Didukung \\
\hline
\end{tabular}

Pengujian hipotesis dalam PLS disebut juga sebagai uji inner model. Uji ini meliputi uji signifikansi pengaruh langsung dan tidak langsung serta pengukuran besarnya pengaruh variabel eksogen terhadap variabel endogen. Untuk mengetahui pengaruh kepemimpinan transformasional terhadap perilaku inovatif pegawai melalui iklim etis sebagai variable mediasi dibutuhkan uji pengaruh langsung dan tidak langsung. Uji pengaruh dilakukan dengan menggunakan uji t-statistik dalam model analisis partial least squared (PLS) dengan menggunakan bantuan software SmartPLS 3.0, Dengan teknik boothstrapping, diperoleh nilai $R$ Square dan nilai uji signifikansi sebagaimana Tabel 5 dan Tabel 6. Hasilnya adalah semua hipotesis (H1, H2, H3, H4) di dukung.

\section{Pembahasan}

Berdasarkan Tabel 5, nilai $R$ Square iklim etis (IE) sebesar 0,353 yang berarti bahwa variable iklim etis (IE) mampu dijelaskan oleh variabel kepemimpinan transformasional (KT) sebesar 35,5\%, sedangkan sisanya sebesar $64,5 \%$ dijelaskan oleh variabel lain yang tidak dibahas dalam penelitian ini. Sementara itu, nilai $R$ Square perilaku inovatif pegawai (PI) sebesar 0,624 yang berarti bahwa variabel perilaku inovatif pegawai (PI) mampu dijelaskan oleh variabel kepemimpinan transformasional (KT) dan iklim etis (IE) sebesar 62,4\%, sedangkan sisanya sebesar $37,6 \%$ dijelaskan oleh variabel lain yang tidak dibahas dalam penelitian ini. Sedangkan Tabel 6 menampilkan t-statistics dan p-values yang menunjukkan pengaruh antar variable penelitian yang telah disebutkan.

Menurut hasil studi ini, kepemimpinan transformasional mempengaruhi secara positif signifikan tehadap iklim etis dan perilaku inovatif pegawai. Iklim etis berpengaruh positif signifikan terhadap perilaku inovatif pegawai. Pengaruh variabel iklim etis terhadap perilaku inovatif pegawai lebih tinggi jika dibandingkan dengan variabel kepemimpinan transformasional, yakni lebih dari tiga kali lipat. Artinya, pada industry manufaktur ini, kondisi iklim etis yang positif lebih dibutuhkan untuk mendorong perilaku inoavasi pegawai. Selain itu, temuan menunjukkan bahwa iklim etis secara parsial memediasi hubungan pengaruh kepemimpinan transformasional terhadap perilaku inovatif pegawai. Selanjutnya, pengaruh kepemimpinan transformasional terhadap perilaku inovatif pegawai juga meningkat ketika iklim etis dimasukkan dalam model, yang secara parsial mengimplikasikan bahwa kepemimpinan transformasional meningkatkan iklim etis, yang pada gilirannya meningkatkan perilaku inovatif pegawai.

Objektif utama dari penelitian ini adalah untuk menilai pengaruh dari beberapa persepsi dan sikap terkait pekerjaan pegawai terhadap perilaku inovatif mereka yang sebagian besar memiliki konsekuensi bagi organisasi perusahaan. Kepemimpinan merupakan faktor penting untuk meningkatkan perilaku inovatif, dan iklim etis merupakan faktor lain yang juga meningkatkannya. Secara khusus dalam studi ini penulis berkonsentrasi pada pengaruh kepemimpinan transformasional terhadap perilaku inovatif 
4667 Inovasi di Era Informasi: Analisis Kepemimpinan Transformasional dan Iklim Etis di Industri Manufaktur Beby Tiara, Vanessa Stefanny, Sukriyah, Dewiana Novitasari, Masduki Asbari

DOI: https://doi.org/10.31004/edukatif.v3i6.1540

pegawai industri manufaktur. Oleh karena itu, manajemen beserta para pemimpin di organisasi perusahaan perlu meningkatkan kualitas praktik kepemimpinan transformasional di lingkungan kerja, hingga dirasakan betul oleh seluruh pegawai. Perilaku pemimpin memiliki pengaruh penting terhadap perilaku pegawai (Asbari et al., 2021b; Asbari \& Novitasari, 2021; Asbari \& Prasetya, 2021; Kamar et al., 2019; Suroso et al., 2021; Yuwono et al., 2020; Zaman et al., 2020a, 2020b). Penting bagi para pemimpin untuk mendapatkan kepercayaan dan kesetiaan bawahan mereka (Nuryanti et al., 2020). Semua harapan tersebut dapat diwujudkan oleh efektivitas praktik kepemimpinan transformasional oleh para pemimpin organisasi. Kepemimpinan transformasional memberikan komitmen dan loyalitas pegawai (Asbari, 2019b, 2019a; Basuki et al., 2020; Hutagalung et al., 2020; Maesaroh et al., 2020; Silitonga et al., 2020). Ketika pegawai percaya dan loyal kepada pimpinannya, maka iklim etis tumbuh kondusif yang pada akhirnya mampu meningkatkan perilaku inovatif pegawai.

\section{KESIMPULAN}

Akhirnya, temuan studi ini mengonfirmasi bahwa kepemimpinan transformasional secara positif dan signifikan mempengaruhi iklim etis dan perilaku inovatif pegawai. Ini menyiratkan bahwa jenis kepemimpinan yang transformatif membantu mendorong inovasi dan kondisivitas iklim etis. Demikian pula, iklim etis mampu memediasi positif hubungan pengaruh kepemimpinan transformasional terhadap perilaku inovatif pegawai industry manufaktur. Temuan dan implikasi ini sebagian besar sejalan dengan literatur yang ada. Namun demikian, penelitian ini juga bukannya tanpa batasan. Tanpa menggunakan studi longitudinal, hubungan antara iklim etis dan perilaku inovatif tidak dapat dipahami dengan baik dan menyeluruh. Penelitian selanjutnya tentang topik ini disarankan dan memang perlu untuk dikembangkan menjadi longitudinal. Dimungkinkan juga untuk memperluas model teoritis dengan memasukkan variabel dependen tambahan seperti komitmen organisasi, OCB, budaya organisasi, dan atau gaya kepemimpinan lainnya.

\section{DAFTAR PUSTAKA}

Asbari, M. (2019a). Pengaruh Kepemimpinan Transformasional Dan Iklim Organisasi Terhadap Kinerja Dosen. JOCE IP, 13(2), 172-186. Http://Jurnal.Ipem.Ac.Id/Index.Php/Joce-Ip/Article/View/187

Asbari, M. (2019b). Pengaruh Kepemimpinan Transformasional Dan Iklim Organisasi Terhadap Kinerja Dosen. Journal Of Communication Education, 13(2), 172-186.

Asbari, M., Fayzhall, M., Goestjahjanti, F. S., Winanti, Yuwono, T., Hutagalung, D., Basuki, S., Maesaroh, S., Mustofa, Chidir, G., Yani, A., \& Purwanto, A. (2020). Peran Kepemimpinan Transformasional Dan Organisasi Pembelajaran Terhadap Kapasitas Inovasi Sekolah. Edupsycouns: Journal Of Education, Psychology And Counseling, 2(1), 6724-6748. Https://Ummaspul.EJournal.Id/Edupsycouns/Article/View/421

Asbari, M., \& Novitasari, D. (2021). Pengaruh Authentic Leadership Terhadap Mentalitas Siap Berubah Dan Kinerja Pegawai Paruh Waktu. Business Management Journal, 17(1), 73-88. Https://Doi.Org/Http://Dx.Doi.Org/10.30813/Bmj

Asbari, M., \& Prasetya, A. B. (2021). Managerial Coaching: Rahasia Membangun Kinerja, Komitmen Tim Dan Modal Psikologis Guru. Edumaspul - Jurnal Pendidikan, 5(1), 490-506. Https://Ummaspul.EJournal.Id/Maspuljr/Article/View/1248

Asbari, M., Purba, J. T., Hariandja, E. S., \& Sudibjo, N. (2021a). From Leadership To Innovation: Managing Employee Creativity. Jurnal Manajemen Strategi Dan Aplikasi Bisnis, 4(1), 143-154. Https://Doi.Org/Https://Doi.Org/10.36407/Jmsab.V4i1.287 
4668 Inovasi di Era Informasi: Analisis Kepemimpinan Transformasional dan Iklim Etis di Industri Manufaktur Beby Tiara, Vanessa Stefanny, Sukriyah, Dewiana Novitasari, Masduki Asbari

DOI: https://doi.org/10.31004/edukatif.v3i6.1540

Asbari, M., Purba, J. T., Hariandja, E. S., \& Sudibjo, N. (2021b). Membangun Kesiapan Berubah Dan Kinerja Karyawan: Kepemimpinan Transformasional Versus Transaksional. Jurnal Ilmiah Manajemen Dan Bisnis, 22(1), 54-71.

Asbari, M., Purwanto, A., \& Budi, P. (2020). Pengaruh Iklim Organisasi Dan Kepemimpinan Transformasional Terhadap Produktivitas Kerja Inovatif Pada Industri Manufaktur Di Pati Jawa Tengah . Jurnal Produktivitas, 7(1), 62-69. Https://Doi.Org/Http://Dx.Doi.Org/10.29406/Jpr.V7i1.1797

Basuki, S., Novitasari, D., Fahlevi, M., Nadeak, M., Fahmi, K., Pebrina, E. T., Sudiyono, R. N., \& Asbari, M. (2020). Performance Analysis Of Female Employees In The Covid-19 Pandemic Period: The Effects Of Readiness For Change And Effectiveness Of Transformational Leadership. Solid State Technology, 63(1s), 201-217.

Bogler, R. (2001). The Influence Of Leadership Style On Teacher Job Satisfaction. Educational Administration Quarterly, 37(5), 662-683. Https://Doi.Org/10.1177/00131610121969460

Briggs, E., Jaramillo, F., \& Weeks, W. (2012). The Influences Of Ethical Climate And Organization Identity Comparisons On Salespeople And Their Job Performance. Journal Of Personal Selling And Sales Management, 32(4), 421-436. Https://Doi.Org/10.2753/PSS0885-3134320402

Chin, W. (1998). The Partial Least Squares Approach To Structural Equation Modeling (E. Modern Methods For Business Research, In: G. A. Marcoulides (Ed.)). Lawrence Erlbaum Associates Publisher.

Creswell, J. W., \& Creswell, J. D. (2017). Research Design: Qualitative, Quantitative, And Mixed Methods Approaches. Sage Publications.

Ebtsam, A. A. H. (2015). Relationship Between Ethical Work Climate And Nurses Perception Of Organizational Support, Commitment, Job Satisfaction And Turnover Intent. Nursing Ethics, 1-16.

Fikri, M. A. A., Asbari, M., Hutagalung, D., Amri, L. H. A., \& Novitasari, D. (2021). Quo Vadis Motivasi Intrinsik Pegawai: Peran Strategis Kepemimpinan Transformasional Dan Kepuasan Kerja. Edukatif: Jurnal Ilmu Pendidikan, 3(6), 4025-4040. Https://Edukatif.Org/Index.Php/Edukatif/Article/View/1397/Pdf

Fornell, C., \& Larcker, D. F. (1981). Evaluating Structural Equation Models With Unobservable Variables And Measurement Error. Journal Of Marketing Research, 18(1), 39. Https://Doi.Org/10.2307/3151312

Ghozali, I. (2014). Structural Equation Modeling, Metode Alternatif Dengan Partial Least Square (PLS) (4th Ed.). Badan Penerbit Universitas Diponegoro.

Hair, J. F., Black, W. C., Babin, B. J., \& Anderson, R. E. (2010). Multivariate Data Analysis (7th Ed.). Pearson Prentice Hall.

Hair, Joe F, Sarstedt, M., Ringle, C. M., \& Mena, J. A. (2012). An Assessment Of The Use Of Partial Least Squares Structural Equation Modeling In Marketing Research. Journal Of The Academy Of Marketing Science, 40(3), 414-433.

Hair Jr, J. F., Sarstedt, M., Ringle, C. M., \& Gudergan, S. P. (2017). Advanced Issues In Partial Least Squares Structural Equation Modeling. Sage Publications.

Hung, R. Y.-Y., Lien, B. Y.-H., Fang, S.-C., \& Mclean, G. N. (2010). Knowledge As A Facilitator For Enhancing Innovation Performance Through Total Quality Management. Total Quality Management, $21(4), 425-438$.

Hutagalung, D., Asbari, M., Fayzhall, M., Ariyanto, E., Agistiawati, E., Sudiyono, R. N., Waruwu, H., Goestjahjanti, F. S., Winanti, W., \& Yuwono, T. (2020). Peran Religiusitas, Kepemimpinan Transformasional, Kepuasan Kerja Dan Mediasi Organizational Citizenship Behavior Terhadap Kinerja Guru. Edupsycouns: Journal Of Education, Psychology And Counseling, 2(1), 311-326.

Jong, J. P. J. D., \& Hartog, D. N. Den. (2008). Innovative Work Behavior: Measurement And Validation. Scientific Analysis Of Entrepreneurship And Smes, November, 1-27. 
4669 Inovasi di Era Informasi: Analisis Kepemimpinan Transformasional dan Iklim Etis di Industri Manufaktur Beby Tiara, Vanessa Stefanny, Sukriyah, Dewiana Novitasari, Masduki Asbari

DOI: https://doi.org/10.31004/edukatif.v3i6.1540

Kamar, K., Novitasari, N., Asbari, M., Winanti, \& Goestjahjanti, F. S. (2019). Enhancing Employee Performance During The Covid-19 Pandemic: The Role Of Readiness For Change Mentality. Jurnal Dinamika Manajemen, 11(2), 154-166. Http://Journal.Unnes.Ac.Id/Nju/Index.Php/Jdm/Article/View/25279

Khasanah, I. F. N., \& Himam, F. (2019). Kepemimpinan Transformasional Kepribadian Proaktif Dan Desain Kerja Sebagai Prediktor Perilaku Kerja Inovatif. Gadjah Mada Journal Of Psychology (Gamajop), 4(2), 143. Https://Doi.Org/10.22146/Gamajop.46361

Maesaroh, S., Asbari, M., Hutagalung, D., Mustofa, M., Agistiawati, E., Basuki, S., Radita, F. R., Nurasiah, N., Yulia, Y., \& Singgih, E. (2020). Pengaruh Religiusitas Dan Kepemimpinan Transformasional Terhadap Kinerja Guru Melalui Mediasi Organizational Citizenship Behavior. Edupsycouns: Journal Of Education, Psychology And Counseling, 2(1), 276-290.

Nedkovski, V., Guerci, M., De Battisti, F., \& Siletti, E. (2017). Organizational Ethical Climates And Employee's Trust In Colleagues, The Supervisor, And The Organization. Journal Of Business Research, $71,19-26$.

Novitasari, D., Supiana, N., Supriatna, H., Fikri, M. A. A., \& Asbari, M. (2021). The Role Of Leadership On Innovation Performance: Transactional Versus Transformational Style. JIMFE (Jurnal Ilmiah Manajemen Fakultas Ekonomi), Https://Journal.Unpak.Ac.Id/Index.Php/Jimfe/Article/View/2981

Nuryanti, Y., Novitasari, D., Nugroho, Y. A., Fauji, A., Gazali, \& Asbari, M. (2020). Meningkatkan Komitmen Organisasional Dosen: Analisis Pengaruh Kepemimpinan Perguruan Tinggi Dan Kepuasan Intrinsik \& Ekstrinsik Dosen. Edupsycouns: Journal Of Education, Psychology And Counseling, 2(1), $561-581$.

Octavia, A., \& Ratnaningsih, I. Z. (2017). Dengan Perilaku Inovatif Karyawan Non Proses ( Supporting) PT Indocement Tunggal Prakarsa Tbk Plant Palimanan. Jurnal Empati, 6(1), 40-44.

Pramono, T., Asbari, M., Supriatna, H., Nugroho, Y. A., \& Novitasari, D. (2021). Rahasia Inovasi Karyawan Wanita Di Era Digital: Analisis Modal Psikologis Dan Dukungan Kepemimpinan. Value: Jurnal Manajemen Dan Akuntansi, 16(2), 1-17. Https://E-Journal.Umc.Ac.Id/Index.Php/VL/Article/View/1924

Purwanto, A., Asbari, M., \& Santoso, T. I. (2021a). Analisis Data Penelitian Manajemen Pendidikan: Perbandingan Hasil Antara Amos, Smartpls, Warppls, Dan SPSS Untuk Jumlah Sampel Kecil. International Journal Of Social, Policy And Law (IJOSPL), 01(01), 111-122. Https://Ijospl.Org/Index.Php/Ijospl/Article/View/64

Purwanto, A., Asbari, M., \& Santoso, T. I. (2021b). Education Management Research Data Analysis: Comparison Of Results Between Lisrel, Tetrad, GSCA, Amos, Smartpls, Warppls, And SPSS For Small Samples. Nidhomul Haq: Jurnal Manajemen Pendidikan Islam, 6(2), 382-399. Https://EJournal.Ikhac.Ac.Id/Index.Php/Nidhomulhaq/Article/View/1575

Purwanto, A., Asbari, M., Santoso, T. I., Haque, M. G., \& Nurjaya. (2019). Marketing Research Quantitative Analysis For Large Sample: Comparing Of Lisrel, Tetrad, GSCA, Amos, Smartpls, Warppls, And SPSS. Jurnal Ilmiah Ilmu Administrasi Publik: Jurnal Pemikiran Dan Penelitian Administrasi Publik, 9(2), 355-372. Https://Ojs.Unm.Ac.Id/Iap/Article/View/22803

Purwanto, A., Asbari, M., Santoso, T. I., Paramarta, V., \& Sunarsih, D. (2020). Social And Management Research Quantitative Analysis For Medium Sample: Comparing Of Lisrel, Tetrad, GSCA, Amos, Smartpls, Warppls, And SPSS. Jurnal Ilmiah Ilmu Administrasi Publik: Jurnal Pemikiran Dan Penelitian Administrasi Publik, 9(2), 518-532. Https://Ojs.Unm.Ac.Id/Iap/Article/View/22804

Purwanto, A., Asbari, M., Santoso, T. I., Sunarsi, D., \& Ilham, D. (2021). Education Research Quantitative Analysis For Little Respondents: Comparing Of Lisrel, Tetrad, GSCA, Amos, Smartpls, Warppls, And SPSS. Jurnal Studi Guru Dan Pembelajaran, 4(2), 335-350. Https://EJournal.My.Id/Jsgp/Article/View/1326 
4670 Inovasi di Era Informasi: Analisis Kepemimpinan Transformasional dan Iklim Etis di Industri Manufaktur Beby Tiara, Vanessa Stefanny, Sukriyah, Dewiana Novitasari, Masduki Asbari

DOI: https://doi.org/10.31004/edukatif.v3i6.1540

Roscoe, A. M., Lang, D., \& Sheth, J. N. (1975). Follow-Up Methods, Questionnaire Length, And Market Differences In Mail Surveys: In This Experimental Test, A Telephone Reminder Produced The Best Response Rate And Questionnaire Length Had No Effect On Rate Of Return. Journal Of Marketing, 39(2), 20-27.

Sarstedt, M., Ringle, C. M., Smith, D., Reams, R., \& Hair Jr, J. F. (2014). Partial Least Squares Structural Equation Modeling (PLS-SEM): A Useful Tool For Family Business Researchers. Journal Of Family Business Strategy, 5(1), 105-115.

Schwepker, C. H. (2001). Ethical Climate's Relationship To Job Satisfaction, Organizational Commitment, And Turnover Intention In The Salesforce. Journal Of Business Research, 54(1), 39-52. Https://Doi.Org/10.1016/S0148-2963(00)00125-9

Sekaran, U., \& Bougie, R. (2003). Research Methods For Business: A Skill Building Approach (Sixth Edit). John Wiley And Sons, Inc.

Setyowati, S., \& Etikariena, A. (2019). Peran Gaya Pemecahan Masalah Dalam Hubungan Kepemimpinan Transformasional Dengan Perilaku Kerja Inovatif. Jurnal Diversita, 5(2), 115-125. Https://Doi.Org/10.31289/Diversita.V5i2.2857

Silitonga, N., Novitasari, D., Sutardi, D., Sopa, A., Asbari, M., Yulia, Y., Supono, J., \& Fauji, A. (2020). The Relationship Of Transformational Leadership, Organizational Justice And Organizational Commitment: A Mediation Effect Of Job Satisfaction. Journal Of Critical Reviews, 7(19), 89-108.

Sukarno, P. A. (2020). Inovasi, Kunci Sukses Industri Bertahan Di Masa Pandemi Corona Inovasi. Bisnis.Com. Https://Ekonomi.Bisnis.Com/Read/20200622/9/1256154/Inovasi-Kunci-Sukses-IndustriBertahan-Di-Masa-Pandemi-Corona

Suroso, Riyanto, Novitasari, D., Sasono, I., \& Asbari, M. (2021). Esensi Modal Psikologis Dosen: Rahasia Kreativitas Dan Inovasi Di Era Education 4.0. Edumaspul - Jurnal Pendidikan, 5(1), 437-451. Https://Ummaspul.E-Journal.Id/Maspuljr/Article/View/1240

Topcu, M. K., Gursoy, A., \& Gurson, P. (2015). The Role Of The Servant Leadership On The Relation Between Ethical Climate Perception And Innovative Work. European Research Studies Journal, 18(1), 67-80. Https://Doi.Org/10.35808/Ersj/440

Yuwono, T., Wiyono, N., Asbari, M., Novitasari, D., \& Silitonga, N. (2020). Analisis Pengaruh Efektivitas Kepemimpinan Transformasional Dan Kesiapan Untuk Berubah Terhadap Kinerja Karyawan Wanita Di Masa Pandemi Covid-19. Jurnal Ilmiah Mahasiswa Ekonomi Manajemen, 5(3), 615-632. Http://Www.Jim.Unsyiah.Ac.Id/EKM/Article/View/15502

Zaman, M. N., Novitasari, D., Goestjahjanti, F. S., Fahlevi, M., Nadeak, M., Fahmi, K., Setiawan, T., \& Asbari, M. (2020a). Effect Of Readiness To Change And Effectiveness Of Transformational Leadership On Workers ' Performance During Covid-19 Pandemic. Solid State Technology, 63(1s), 185-200. Http://Www.Solidstatetechnology.Us/Index.Php/JSST/Article/View/708 